\title{
ЕВОЛЮЦІЯ ЕКОНОМІЧНОГО ЗМІСТУ ІННОВАЦЙ ТА ЙОГО СПЕЦИФІКА НА СУЧАСНОМУ ЕТАПІ СОЦІАЛЬНО-ЕКОНОМІЧНИХ ВІДНОСИН
}

\author{
Луцький національний технічний університет
}

Новітня доба глобальних соціально-економічних трансформацій перетворила мобільність у фактично єдину стійку характеристику розвитку бізнес-діяльності. Сучасні прояви мобільності сучасного господарського процесу передбачають швидку реакцію на мінливість умов кон'юнктури національного та світового ринків, розбудову формального та неформального інституціонального середовища, асиметрію інформації, розвиток глобальної господарської системи і т.п. Динамічність сучасних умов розвитку зумовлює необхідність формування та розбудови інноваційно-інвестиційної моделі розвитку, як найуспішнішої і найперспективнішої.

Інноваційний процес передбачає декілька суттєвих етапів від виявлення інноваційного попиту до поширення освоєної інновації і її комерціалізації.

Економічний зміст інноваційних процесів цікавив науковців практично з виникнення економічної теорії, але як предмет спеціального наукового осмислення інновації стали у ХХ ст.

У статті досліджено особливості еволюції поглядів вітчизняних та зарубіжних вчених щодо трактування поняття «інновації» та розвитку інноваційної парадигми. Вчені різних періодів надавали різного змісту інноваціям: по-перше, розглядали як результат НТП, інноваційної діяльності та практичного / технічного використання новацій; по-друге: як цільові зміни у функціонуванні підприємства та якісні зміни усіх елементів суспільного виробництва; по-третє: як систему або комплекс заходів щодо впровадження нової техніки, технології і т.п.; по-четверте: як процес створення та практичного використання новацій та відтворення економічного елемента через нову ідею, винахід чи процес; по-п'яте: як комерційне рішення чи продукт інноваційної діяльності.

У статті обгрунтовано прямий вплив розвитку інноваційних процесів на рівень конкурентоспроможності, а також запропоновано комплексне трактування дефініції «інновації» зважаючи на особливості сучасних соціально-економічних трансформацій: акцентована увага на необхідності постійних інвестицій та оптимальної інноваційно-управлінської інфраструктури на мікро-, макро-, мезота мегарівнях.

Ключові слова: інновація, інноваційний процес, конкурентоспроможність, інноваційна система, інновачійна інфраструктура.

\section{EVOLUTION OF THE ECONOMIC CONTENT OF INNOVATION AND ITS SPECIFICS AT THE CURRENT STAGE OF SOCIO-ECONOMIC RELATIONS}

\author{
Lutsk National Technical University
}

The latest era of global socio-economic transformations has turned mobility into virtually the only sustainable characteristic of business development. Modern manifestations of mobility of the modern economic process involve a rapid response to changing conditions of national and world markets, the development of formal and informal institutional environment, information asymmetry, the development of the global economic system, etc. The dynamism of modern conditions of development necessitates the formation and development of innovation and investment model of development, as the most successful and most promising.

The innovation process involves several significant stages from the identification of innovative demand to the spread of mastered innovation and its commercialization.

The economic content of innovation processes has interested scientists almost since the emergence of economic theory, but as a subject of special scientific understanding of innovation in the twentieth century.

The article examines the peculiarities of the evolution of views of domestic and foreign scientists on the interpretation of the concept of «innovation» and the development of the innovation paradigm. Scientists of different periods provided different content of innovations: first, considered as a result of STP, innovation and practical / technical use of innovations; secondly: as targeted changes in the functioning of the enterprise and 
qualitative changes in all elements of social production; third: as a system or set of measures for the introduction of new equipment, technology; fourth: as a process of creation and practical use of innovations and reproduction of an economic element through a new idea, invention or process; fifth: as a commercial solution or product innovation activity.

The article substantiates the direct impact of innovation processes on the level of competitiveness, and also offers a comprehensive interpretation of the definition of «innovation» taking into account the peculiarities of modern socio-economic transformations: emphasis on the need for continuous investment and optimal innovation and management infrastructure at the micro, macro, meso and mega levels.

Keywords: innovation, innovation process, competitiveness, innovation system, innovation infrastructure.

Постановка проблеми у загальному вигляді та іiї зв'язок 3 важливими науковими і практичними завданнями. Інноваційна діяльність в сучасних умовах глобальних соціально-економічних трансформацій є важливим чинником, що впливає на усі сфери розвитку як окремих країн, так і цілих регіонів світу. Глобалізація фактично $\epsilon$ першопричиною необхідності нарощення ефективності інноваційної діяльності i провокує ще більше відставання, так званих, країн третього світу від промислово розвинених держав. Високорозвинені країни світу виступають центрами тяжіння інвестицій i, як наслідок, є продуцентами передових інновацій в усіх сферах суспільного виробництва, і у такий спосіб отримують кращі умови для самореалізації.

Прогресуючі явища сучасного суспільства i гостра потреба необхідності формування конкурентоспроможних бізнес сфер виробництва та послуг зумовлюють пряму залежність від інновацій. Саме цим і зумовлюється актуальність ретроспективного дослідження дефініції поняття «інновації» та приведення iï у відповідність до сучасних соціально-економічних відносин.

Аналіз останніх досліджень, у яких започатковано вирішення проблеми. Теоретичним та практичним аспектам інноваційної парадигми, проблемам інноваційної діяльності та інноваційного розвитку присвячена досить чисельна кількість наукових праць вітчизняних та зарубіжних вчених. А саме:

- XVIII ст.: А. Сміт, Ж. Кондорсе, Д. Рікардо, Ж. Сей та ін.;

- XIX ст.: К. Маркс, М. Туган-Барановський, Й. Шумпетер;

- ХХ ст.: М. Абрамовиц, А. Анчішкін, Ю. Бажал, Л. Барютін, Л. Водачек, О. Водачкова, В. Геэць, Е. Денісон, А. Казанцев, Д. Кендрік, М. Кодратьєв, С. Кузнец, В. Кушлін, О. Лапко, К. Макконнелл, Е. Менсфілд, Г. Менш, Р. Мюллер, К. Познанський, М. Портер, Х. Рігс, Е. Роджерс, Б. Санто, Р. Солоу, Б.Твісс, Р. Фостер, П. Харів, М. Хучек, Н. Чухрай, Ю. Яковець та ін.;

- XXI ст.: М. Авсянніков, Л. Антонюк, І. Балабанов, О. Богашко, О. Дацій, В. Дубіченко, Б. Заблоцький, В. Занько, М. Зубовець, С. Ілляшенко, А. Кругліков, В. Мединський, С. Мочерний, Р. Нельсон, 3. Пересунько, А. Поручник, О. Прокопенко, В. Савчук, Н. Сиротинська, С. Тивончук, Й.Тідд, В. Томпсон, С. Уінтер, П. Харів та ін.

Однак, незважаючи на велику кількість праць та цінність проведених досліджень, категорія «інновації» $\epsilon$ досить динамічним поняттям, яке потребує постійного удосконалення зважаючи на швидкозмінний характер соціально-економічних відносин від мікро- до мегарівня. Саме тому, існує об'єктивна необхідність в грунтовному дослідженні існуючих підходів до трактування економічного змісту категорії «інновації», їх систематизації та приведення у відповідність до сучасних соціальноекономічних трансформацій.

Цілі статті: дослідити особливості еволюції поглядів вітчизняних та зарубіжних вчених щодо трактування поняття «інновації» та розвитку інноваційної парадигми, систематизувати існуючі підходи, запропонувати комплексне трактування дефініції «інновації» зважаючи на особливості сучасних соціально-економічних трансформацій.

Виклад основного матеріалу дослідження 3 обгрунтуванням отриманих наукових результатів. Новації цікавили людей завжди, адже це необхідний елемент для 
покращення рівня добробуту. Вони існують 3 моменту першого практичного кроку людини в напрямку покращення свого життя. Перші згадки про інновації зустрічаються у працях давньогрецьких мислителів: у «Домострої» Ксенофонта, «Політиці» Платона, «Нікомаховій етиці» Арістотеля прослідковуються чіткі думки щодо доцільності здійснення діяльності, що покращує здійснення практичних операцій і загалом піднімає продуктивність праці. Зокрема, Ксенофонт зазначав, що поділ праці $є$ новацією у процесах організації виробництва [1, с. 18]. Однак, праці згаданих давньогрецьких дослідників не можна вважати повноцінним зародженням інноваційної теорії, оскільки їхні погляди у даній царині мають фрагментарних характер, жоден 3 них інноваційні процеси не відніс до одного з основних об'єктів свого дослідження.

Зародки економічних знань стосовно визначення ролі інноваційних процесів прослідковуються у теорії класичної школи політичної економії (XVIII-XIX ст.). це пояснюється тим, що одним з об'єктів дослідження даної школи була сфера виробництва. А саме, у працях А. Сміта, Ж. Кондорсе, Д. Рікардо, Ж.Б. Сея та К. Маркса досить чітко окреслено місце інновацій у підвищенні ефективності усіх сфер суспільного виробництва.

У науковій праці А. Сміта «Дослідження про природу і причини багатства народів» $є$ твердження про те, що зростання продуктивності праці може бути зумовлене винайденням машин, які спрощують працю та підвищують іï продуктивність. Саме розподіл праці та зосередженість на виконанні окремих операцій сприяло винайденню кращого способу їх здійснення (полегшення та пришвидшення) [2, с. 214-219].

Сучасник А. Сміта, французький вчений Ж.Кондорсе у своїй праці «Ескіз історичної картини прогресу людського розуму» (1795р.) досліджував взаємовплив розвитку промислового виробництва та стану наукових розробок. Вчений вважав, що наукові доробки забезпечують прогрес промислового сектору, який, у свою чергу, впливає на ефективність науки та сприяє виходу ії на новий рівень розвитку. Результатом такого взаємозв'язку є людський та економічний розвиток [3, с.250-258].

Англійський вчений Д. Рікардо у своїй праці «Принципи політичної економії $\mathrm{i}$ оподаткування» (1817p.) більш грунтовніше за своїх попередників розглядає особливості науково-технічного прогресу та його вплив на загальноекономічний макроекономічний розвиток: зростання рівня оплати праці стимулює до більших капіталовкладень, наслідком чого $є$ витіснення ручної праці машинною і виникнення технологічного безробіття; технологічні зміни лише ті є корисними, які підвищують продуктивність праці (якщо ж даний ефект не досягається, то новації жодним чином не впливають вартість капіталу та праці) [4].

Згадки доцільності впровадження інновацій у господарський процес зустрічаються у працях українського вченого Михайла Туган-Барановського. А саме у творі «Промислові кризи у сучасній Англії, їх причини і вплив на народне життя» (1894 р.). зазначено те, що держава зобов'язана створювати сприятливі умови та надавати підтримку створенню наукових розробок, їх апробації та впровадженню у виробництво. На думку М.Туган-Барановського першопричиною промислових криз є технічний рівень засобів праці, а зростання їх ефективності є поштовхом для економічного зростання. М. Туган-Барановський першим застосував підхід відтворення щодо дослідження нерівномірного розвитку економіки під впливом НТП. Вчений вважав, що інновації тісно пов'язані з циклічністю економічного розвитку. Крім того, М.Туган-Барановський першим зосередив увагу на тому, що інновації зумовлюються інвестиціями [5].

Наукові розробки українського вченого Михайла Туган-Барановського стали основою багатьох авторських напрацювань українських та зарубіжних дослідників у сфері розвитку інноваційної парадигми, повноцінного вигляду, яка почала набувати у середині XX ст. Серед вагомих напрацювань щодо розробки теорії інновацій варто згадати погляди та наукові розробки М. Кондратьєва, зокрема його працю «Великі цикли 
кон'юнктури і теорія передбачення» (1928р.). Дослідник аналізував фактичні статичні дані економічного розвитку, на той час, провідних капіталістичних країн світу: США, Англії, Німеччини та Франції. Провівши моніторинг макроекономічних показників за довгостроковий період, вчений довів існування «довгих хвиль» із тривалістю 54 роки. Першопричиною довгострокових економічних коливань науковець називає зміну базових технологій, використовуваних для здійснення суспільного виробництва країни. Глибина і новизна застосовуваних нововведень $\epsilon$ визначальною при стимулюванні економічного розвитку, як окремого суб'єкта господарювання, так і національного суспільного виробництва. Окрім інноваційних змін, серед визначальних причин «довгих хвиль» науковець називає трансформації суспільного життя, які можуть переходити у форми прояву довгострокових циклічних коливань в економіці [6, с. 219-236]. М.Д. Кондратьєв також довів та статистично обгрунтував, що фази «довгих хвиль» (висхідна і низхідна) визначаються не чинниками, що супроводжують цикл, а тими процесами, що відбуваються двома десятиліттями раніше і накопиченими ефектами від їх взаємодії [6, c. $358-362]$.

Активним дослідником та розробником повноцінної теорії інноваційного розвитку був австрійський вчений-економіст Й. Шумпетер [7], який розглядав їх, поперше, як економічний вплив організаційної форми на трансформацію та диверсифікацію продукції, який перетворює цю продукцію з традиційної на нову. Подруге, він намагався розкрити сутність інновації з точки зору системної корисності, як нового процесу і нового результату. По-третє, розглядав інновацію 3 точки зору комбінації новим способом існуючих факторів виробництва. Й. Шумпетер, розвиваючи ідеї М. Кондратьєва, вважається представником класичної теорії інновацій та інноваційного розвитку, період активного формування якої припадає на 50-ті pp. XIX ст. - 50-ті pp. ХХ ст. Й. Шумпетер та його послідовники стверджують, що заміна техніки та технологій лише тоді буде ефективною, якщо відбуватиметься не у зв'язку з фізичним зношенням, а через зниження конкурентоспроможності виробника та норми прибутки його діяльності. Бажання підвищити дані показники має бути головним стимулом нововведень. На думку Шумпетера Й. саме від підприємницького середовища має поширюватись ініціатива інноваційної діяльності не окреслюючи регулюючого впливу держави на даний процес. Вчений доводить, що поява нововведень в економічній системі не є рівномірним процесом, а залежить від базових інновацій та існуючого технологічного устрою (наприклад, механізація праці в текстильній промисловості викликала цикл 1790-1840 рр., паровий двигун та залізниця - 1840-1890 рр., електрифікація та чорна металургія - 1890-1940 рр., органічна хімія та розвиток нафтової промисловості - 1940-1990pp.) [8, с. 156-159].

Беззаперечними досягненнями Й. Шумпетера у розвитку інноваційної парадигми $\epsilon$ відокремлення простого відтворення через пристосування до змінних економічних умов господарювання від конкретних динамічних змін зумовлених конкретною потребою, що супроводжується появою нових технологій / товарів / ринків збуту /сировини / напівфабрикатів та проведенням реорганізації. Головну роль у ініціації та впровадженні інновацій відіграють підприємці-новатори, а не держава.

Розглядаючи економічний зміст інновацій не можна залишити поза увагою кейнсіанську концепцію. Джон Кейнс у 30-50-их роках XX ст. активно обгрунтовував i відстоював думку про те, що ринкова економіка не здатна бути ефективною та дієздатною. Він вважав за необхідне державне втручання в усі сфери господарського життя та пропонує цілий комплекс інструментів та механізмів. Окрім того Дж. Кейнс та його прихильники досліджували економічну систему у короткостроковому періоді при фіксованих державою цінах [9, с. 342-354]. Дж. М. Кейнс насправді не розглядає інновації як базову умову ефективності економіки, але ним запропоноване та 
обгрунтоване використання за певних умов комплексу організаційно-структурних інновації в державному регулюванні [10].

В 50-их рр. XX ст. американські вчені М. Абрамовиц, Е. Денісон, Д. Кендрік, досліджуючи економічні зміни в США, виявили у довгостроковому періоді закономірність швидшого приросту ВНП відносно приросту використання капітальних та трудових ресурсів. Дослідники обгрунтували даний факт активним використанням науки і техніки у суспільному виробництві [11].

Аналогічними були твердження Р. Солоу: вчений дослідивши макроекономічні показники результативності національної економіки США за сорокарічний період (1909-1949 рр.) вирахував причинно-наслідковий взаємозв'язок - приріст вдвічі валової продукції відбувся на 87,5\% у зв'язку з якісними технологічними змінами і на $12,5 \%$ зі зростанням капіталоозброєності праці [12].

На даному періоді розробки концепції інновацій припадає виникнення соціальнопсихологічної теорії інновацій, розробниками якої $€ \mathrm{X}$. Барнет, $Є$. Вітте, Денісон. Вчені доводили, що у менеджменті інноваційних процесів основна роль належить особистісним характеристикам суб'єктів: освіченість та обізнаність у інноваціях, соціально-психологічні, організаційні та соціологічні чинники сприйнятливості інновацій і т.п. [13, с. 401].

Друга половини XX ст. характеризується наявністю проблем освоєння нових технологій. Зміна базових технологій призвела до кардинальних перемін в усіх сферах суспільного виробництва та людської взаємодії. Поява мікроелектронних технологій спровокувала значний лаговий розрив між впровадження нової технології у виробництво та адаптацією суспільства до неї. Глобальний характер даної проблеми на той час зумовив велику увагу до даного питання, яка виражалась великою кількість наукових публікацій та міжнародних симпозіумів присвячених вирішенню даної проблеми.

Американський соціолог Еверетт Мітчел Роджерс у своїй праці «Дифузія інновацій» виділив п'ять етапів дифузії інновацій: знання, переконання, вирішення (відхилення або прийняття), реалізація та підтвердження [14, с. 118]. Е. Роджерс виокремлює характерні риси інновацій, на які, в першу чергу, звертають увагу та оцінюють індивіди при ухваленні рішення щодо прийняття чи відхилення інновацій: перевага відносно існуючих аналогів, можливість суміжного використання існуючих об'єктів/процесів та новітніх, відповідність системі цінностей потенційного споживача, легкість апробації та використання, наявність очевидних переваг зумовлених ефективністю використання [14, с. 217].

Погляди американського дослідника-економіста Браяна Чарльза Твісса $\epsilon$ відмінними від класичних інноваційних концепцій, оскільки він визначає інновації не як певні зміни, а як процес відтворення економічного елемента через нову ідею, винахід чи процес. Інноваційна процедура, на думку Б. Твісса, передбачає обов'язково економічний зміст, що виражається через орієнтацію на ринок та споживача, здатність задовольняти нові потреби та відповідати цілям індивідів та інституційних суб'єктів, обов'язкову систему відбору ідей та управління ними і т.п. [15].

Американський дослідник Е. Менсфілд доповнює інноваційні погляди своїх попередників тим, що додає ще одну особливість інновацій: «з початком застосування винахід перетворюється на науково-технічне нововведення» [16].

В нобелівській лекції С.Кузнець сформулював власні підходи в концепції інновацій, розвиваючи ідеї Й. Шумпетера і Дж. Бернала. Вченим було введено поняття «епохальні інновації». Вчений доводить, що джерелом економічного росту в індустріальну епоху є прискорення розвитку науки. Також С. Кузнець зазначає, що соціальні наслідки технологічних інновацій можуть бути не лише позитивними, але й негативними, пом'якшенням та, по можливості, недопущенням яких має займатись 
державний апарат. Однак позитивні аспекти, на думку С.Кузнеця, значно переважають в технологічних нововведеннях і основна їх роль полягає у локомотивному ефекті: запускають інноваційні зміни в усіх інших сферах людської взаємодії [17, с. 257].

Значні напрацювання щодо розробки концепції інновацій були у німецьких вчених. Зокрема, професор Г. Менш був послідовником та продовжувачем поглядів Й. Шумпетера. Дослідником була уточнена класифікація інновацій і висунена гіпотеза про те, що базові інновації не є постійними, їх виникнення має хвилеподібний характер і пов'язане з кризами та піками економічного зростання [18, с. 38]. Саме цими поглядами теорія Г. Менша підтверджує послідовність з теорією кон'юнктури Й. Шумпетера і теорією циклів М.Кондратьєва. Дослідник довів, що недостатність інновацій провокує виникнення економічних криз. Вирішити дану проблему Г. Менш пропонує державним втручанням: державні проекти інноваційних змін, співпраця державних інституцій з бізнес середовищем щодо компенсації ризиків пов'язаних 3 дефіцитом новацій на певному етапі розвитку економічної системи.

Польський вчений К. Познанський під інноваціями розуміє зміни будь-якого характеру у способах та технологіях виробництва, зміни у товарах і т.п., які $є$ новими для даного технологічного способу виробництва [19, с.21].

Загалом неокласичні погляди на роль інновацій на економічне зростання та ефективні трансформації економічної системи є досить чисельними, багатогранними та місткими на різноманітні ідеї, але усі вони схожі в тому, що нарощення інновацій є визначальним ендогенним чинником забезпечення довготривалого економічного зростання.

Період починаючи з 90-их рр. ХХ ст. є досить плідним на дослідження природи, особливостей та ролі інновацій у процесах забезпечення сталого економічного розвитку та зростання добробуту усіх інституційних одиниць.

Л. Барютін інновації розглядає як «процес, що управляється, має комплексний характер і передбачає впровадження різноманітних змін в існуючі системи і структури 3 метою створення, розповсюдження i використання принципово нового або модифікованого практичного засобу, який задовільняє конкретні суспільні потреби і створює економічний, технічний або соціальний ефект» [20, с.12].

Вчений Б. Санто трактує інновації як процес суспільного, технічного та економічного характеру, передбачає впровадження ідей та винаходів в практичну діяльність 3 метою створення виробів та технологій з кращими властивостями [21, с. 76-81].

М. Хучек визначає три характерні риси інновацій: функціональна ознака (інновації - це зміни у техніці, технології, організації виробництва); атрибутивна ознака (інновації - це результат зростаючих потреб суспільства); предметна ознака (інновації це нові засоби та предмети праці) [22, с. 87-92].

Науковці С. Ілляшенко та О. Прокопенко вважають, що інновація - є результатом певної діяльності, відображається у нових / удосконалених товарах, послугах, технологіях виробництва, способах управління, що допомагають підвищити ефективність діяльності підприємства [23, с. 184-196].

Науковці-економісти Л. Антонюк, А. Поручник, В. Савчук трактуючи зміст інновацій зосереджують свою увагу на нових подіях, новаторстві чи будь-яких змінах діяльності підприємства для підвищення рівня конкурентоспроможності на вітчизняному та закордонному ринках [24].

Б. Заблоцький трактує інновації як процес, що формує нове мислення, створює, розробляє, впроваджує у виробниче використання, розповсюджує нове технічне, товарне, системне, соціальне, екологічне та інше рішення (новації), яке має за мету задовольнити визначену виробничу, соціальну потребу чи національний інтерес $[25$, с. 118$]$.

На думку Н.Сиротинської доцільно розрізняти поняття «інновація» та «інноваційний процес». Науковець пропонує інновації на підприємстві трактувати, як «кінцевий результат 
інноваційного процесу із впровадження новацій, які завдяки інвестиційним капіталовкладенням втілилися у нових або удосконалених товарах (послугах), технологіях, способах організації виробництва та збуту продукції» [26, с. 402].

Науковець 3. Пересунько виокремлює інновації та інноваційну діяльність. Зокрема, в інноваційній діяльності дослідник вбачає комплекс інноваційних процесів, який у свою чергу, є модернізацією наявних методів, підходів, продуктів, принципів або ж створення нових методів, підходів, продуктів, принципів в усіх сферах, що базуються на нових знаннях. 3. Пересунько трактує поняття «інновація», як результат інноваційного процесу, а також наголошує, що інноваційний розвиток обов'язково повинен мати інтенсивний характер [27].

Розглядаючи зміст категорії «інновації» доцільно звернутись до чинної нормативно-правової бази, а саме до Закону України «Про інноваційну діяльність», згідно якого «інновації - новостворені (застосовані) i (або) вдосконалені конкурентоздатні технології, продукція або послуги, а також організаційно-технічні рішення виробничого, адміністративного, комерційного або іншого характеру, що істотно поліпшують структуру та якість виробництва і (або) соціальної сфери» [28].

Вперше на міжнародному рівні класифікація інноваційної діяльності була розроблена у італійському місті Фраскаті Організацією економічного співробітництва i розвитку. Загалом, у підсумку було підготовлено і видано методологічні довідники «сімейства Фраскаті» [29]:

- Frascati Manual - комплекс стандартів для експертів країн - членів Організації економічного співробітництва і розвитку, які займаються зібранням і публікацією інформації про проекти у сфері НДДКР [30];

- Oslo Manual - комплекс стандартів для вимірювання інноваційного процесу та науково-технологічної активності [31]. У даному документі визначено інновації як «введення в експлуатацію будь-якого нового або значно поліпшеного продукту (товару або послуги) або процесу, нового методу маркетингу або нового організаційного методу у діловій практиці, організації робочих місць або зовнішніх зв'язках» [31, с. 31];

- Canberra Manual - комплекс стандартів щодо вимірювання якості та активності трудових ресурсів, що залучені до діяльності щодо розробки інноваційних проектів [32];

- National Innovation Systems - комплекс стандартів щодо регламентації обміну інноваційними напрацюваннями між інститутами національних інноваційних систем (підприємства, 3ВО, дослідницькі центри, науково-дослідні інститути і т.п.) [33];

- The Knowledge-based Economy - посібник присвячений окресленню ролі наукових досліджень у забезпеченні економічного розвитку [34];

- Interpreting Technology Balance Manual - комплекс стандартів, що окреслює методи, які застосовуються для дослідження міжнародного обміну технологіями [35].

3 метою кращого розуміння історичного генезису теорії інновацій та виокремлення аспектів, які потребують уточнення та доповнення за сучасних умов глобальних соціально-економічних трансформацій, розвитку інституціоналізму та індустріального суспільства доцільно систематизувати погляди дослідників стосовно інновацій та ролі технологічних змін для забезпечення економічного зростання та належного рівня забезпечення потреб усіх рівнів. Зокрема, очевидним є окреслення п'яти підходів у еволюції поглядів дослідників, вітчизняної та міжнародної нормативноправової бази щодо змісту та ролі інновацій в економічній системі (таблиця 1).

3 вище наведених поглядів вчених стосовно розвитку інноваційної концепції стає очевидним, що вона перебуває на стадії формування і особливо активізуються дослідження природи та характеру інноваційних змін під час кризових проявів в економіці та соціально-економічних трансформацій. 
Підходи до трактування поняття «інновації» та розвитку інноваційної парадигми

\begin{tabular}{|c|c|c|}
\hline \multicolumn{3}{|c|}{ Iнновації } \\
\hline $\begin{array}{c}\text { як результат } \\
\text { НТП, інноваційної } \\
\text { діяльності та практичного / } \\
\text { технічного використання } \\
\text { новацій }\end{array}$ & $\begin{array}{l}\text { XVIII ст.: А. Сміт, Ж. Кондорсе, Д. Рікардо, } \\
\text { Ж. Сей } \\
\text { XX ст.: Е. Менсфілд, С. Кузнец, В. Кушлін } \\
\text { ХХІ ст.: І. Балабанов, М. Авсянніков, П. Харів, } \\
\text { С. Ілляшенко, О. Прокопенко, М. Зубовець, } \\
\text { С. Тивончук, В. Занько, Н. Сиротинська, } \\
\text { 3. Пересунько та ін. }\end{array}$ & \multirow{2}{*}{$\begin{array}{l}\text { ХІХ ст.: } \\
\text { К. Маркс, } \\
\text { Й. Шумпетер } \\
\text { ХХ ст.: } \\
\text { М. Хучек }\end{array}$} \\
\hline $\begin{array}{c}\text { як цільові зміни } \\
\text { у функціонуванні } \\
\text { підприємства та якісні } \\
\text { зміни усіх елементів } \\
\text { суспільного виробництва }\end{array}$ & $\begin{array}{l}\text { ХІХ ст.: М. Туган-Барановський } \\
\text { ХХ ст.: М. Кодратьєв, М. Абрамовиц, Е. Денісон, } \\
\text { Д. Кендрік, Р. Солоу, Р. Мюллер, Е. Роджерс, } \\
\text { Г. Менш, Р. Фостер, М. Портер, К. Познанський, } \\
\text { А. Анчішкін, Л. Водачек, О. Водачкова, } \\
\text { Ю. Бажал, Ю. Яковець та ін. } \\
\text { ХХІ ст.: О. Дацій, В. Мединський, О. Богашко, } \\
\text { Р. Нельсон, С. Уінтер та ін. }\end{array}$ & \\
\hline $\begin{array}{c}\text { як система } \\
\text { або комплекс заходів щодо } \\
\text { впровадження нової } \\
\text { техніки, технології і т.п. }\end{array}$ & \multicolumn{2}{|l|}{$\begin{array}{l}\text { XX ст.: О. Лапко та ін. } \\
\text { XXI ст.: В. Дубіченко та ін. }\end{array}$} \\
\hline $\begin{array}{c}\text { як процес } \\
\text { створення та практичного } \\
\text { використання новацій та } \\
\text { відтворення економічного } \\
\text { елемента через нову ідею, } \\
\text { винахід чи процес }\end{array}$ & \multicolumn{2}{|c|}{$\begin{array}{l}\text { XX ст.: Б.Твісс, Л. Барютін, Б. Санто } \\
\text { ХХІ ст.: А. Кругліков, Б. Заблоцький, С. Мочерний, В. Томпсон, } \\
\text { Л. Антонюк, А. Поручник, В. Савчук, Й. Тідд, Oslo Manual та ін. }\end{array}$} \\
\hline $\begin{array}{c}\text { комерційне рішення чи } \\
\text { продукт: } \\
\text { кінцевий результат } \\
\text { інноваційної діяльності }\end{array}$ & \multicolumn{2}{|c|}{$\begin{array}{l}\text { ХХ ст.: В. Геэць, А. Казанцев, К. Макконнелл, П. Харів, Н. Чухрай, } \\
\text { Х. Рігс } \\
\text { ХХІ ст.: Закон України «Про інноваційну діяльність», ДСТУ ГОСТ } \\
\text { 31279:2005 (Інноваційна діяльність. Терміни та визначення понять } \\
\text { (ГОСТ 31279-2004, IDT) }\end{array}$} \\
\hline
\end{tabular}

Проведений бібліографічний огляд міжнародної та вітчизняної законодавчонормативної бази, наукової, монографічної та періодичної літератури, вивчення точок зору науковців за декілька століть дає можливість зробити висновок про те, що інновації $\epsilon$ досить містким поняттям та комплексною дефініцією, а також одним 3 найактуальніших явищ для забезпечення високого рівня конкурентоспроможності підприємства чи країни, особливо за умов глобальних соціально-економічних трансформацій.

В таблиці 2 пропонуємо комплексне трактування економічної категорії «інновації» з врахуванням сучасних особливостей господарської діяльності.

Висновки. Таким чином, на нашу думку, комплексно трактуючи інновації, доцільно їх розглядати як результат синтезу нових ідей у процесі НДДКР, які, як правило, мають невипадковий та цільовий характер (для реалізації незадоволених потреб в існуючих або нових ринкових нішах), впроваджені у виробництво та комерціалізовані, потребують інвестицій та оптимальної інноваційно-управлінської інфраструктури, що здійснюються 3 метою покращення конкурентних позицій та отримання комерційного успіху, соціального та екологічного ефекту на мікро-, макро-, мезо- та мегарівнях.

Комплексна характеристика категорії «інновації» 


\begin{tabular}{|c|c|c|}
\hline & Ознака & Характеристика \\
\hline & 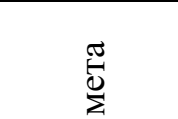 & $\begin{array}{l}\text { недопущення виникнення проблем } \\
\text { вирішення наявної проблеми } \\
\text { задоволення потреб споживачів (явних, прихованих) }\end{array}$ \\
\hline & характер & 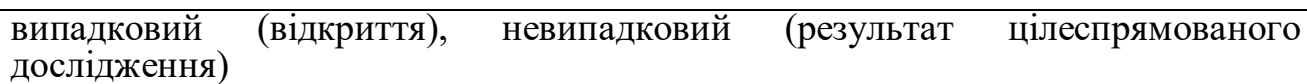 \\
\hline & результат & $\begin{array}{l}\text { втілення нової ідеї; отримання економічного, соціального, екологічного та } \\
\text { інших видів ефекту }\end{array}$ \\
\hline & 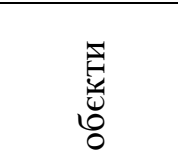 & $\begin{array}{l}\text { якісно нові, якісно покращенні: } \\
\text { - економічні блага (товари, роботи, послуги) } \\
\text { - виробничі, маркетингові, організаційні, управлінські методи, підходи, } \\
\text { принципи }\end{array}$ \\
\hline & суб’єкти & $\begin{array}{l}\text { індивіди та інституційні учасники інноваційного процесу мікро-, макро-, мезо- } \\
\text { та мегарівня }\end{array}$ \\
\hline 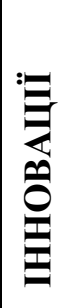 & 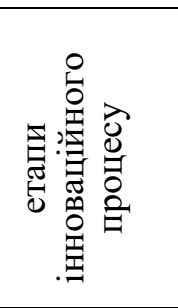 & $\begin{array}{l}\text { Етап } 1 \text { «Передвиробничий»: дослідження незадоволених потреб в існуючих } \\
\text { або нових ринкових нішах } 3 \text { метою виявлення та забезпечення інноваційного } \\
\text { попиту; синтез нових ідей, знань, раціоналізаторських пропозицій і т.П.; } \\
\text { виконання НДДКР } \\
\text { Етап } 2 \text { «Виробничий»: впровадження результатів етапу } 1 \text { у практичну } \\
\text { діяльність } 3 \text { метою задоволення визначених потреб інноваційного характеру та } \\
\text { перетворення їх на інновацію } \\
\text { Етап } 3 \text { «Ринковий»: поширення освоєної інновації, ії комерціалізація }\end{array}$ \\
\hline & : & $\begin{array}{l}\text { покращення } \\
\text { конкурентних } \\
\text { позицій**, } \\
\text { комериійний }\end{array}$ \\
\hline & 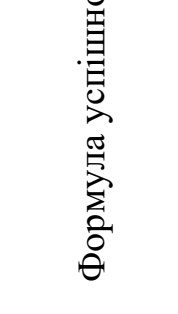 & $\begin{array}{l}\text { * Оптимізація системи управління передбачає: } \\
\text { - наявність бажання та стимулів до інновацій на мікро-, макро-, мезо- та мегарівнях; } \\
\text { - створення відповідної інноваційної інфраструктури; } \\
\text { - створення умов для збереження, розвитку і використання науково-технічного та } \\
\text { інноваційного потенціалу на мікро-, макро-, мезо- та мегарівнях; } \\
\text { **Покрашення конкурентних позицій передбачає підвищення ефективності } \\
\text { позиціювання на ринку, вдосконалення виробничо-збутової діяльності, підвищення } \\
\text { ефективності організації робочих місць, підвищення безпеки життя і здоров'я людей, а } \\
\text { також зниження негативного впливу на навколишнє середовище }\end{array}$ \\
\hline
\end{tabular}

Отже, інновації мають здатність підвищувати якість життя, але лише за умови постійного характеру, функціонування оптимальної інноваційно-інвестиційної моделі 3 виваженою державною політикою їх стимулювання та регламентації.

\section{Список бібліографічного опису}

1.Череп А. В., Маркова С. В. Оцінка ефективності інноваційно-інвестиційної діяльності підприємств лікерогорілчаної промисловості : монографія. Держ. вищ. навч. закл. «Запоріз. нац. університет Міністерства освіти і науки, молоді та спорту України». Запоріжжя: Запоріз. нац. ун-т, 2012. 283 с.

2.Смит А. Исследование о природе и причинах богатства народов / вступ. стат. и коммент. В.С.Афанасьева. М.: Соцэгиз, 1962. $684 \mathrm{c.}$

3.Кондорсэ Ж. Эскиз исторической картины прогресса человеческого разума [пер. с фр.]. М.: Ютиэкньй дом «ЛИБРОКОМ», 2011. $280 \mathrm{c}$.

4.Ricardo D. On The Principles of Political Economy and Taxation. John Murray, 1817.

5.Туган-Барановский М.И. Промышленные кризисы. Очерк из социальной истории Англии. К.: Наукова думка, 2004. $368 \mathrm{c}$.

6.Кондратьев Н.Д. Большие циклы конъюнктуры и теория предвидения. М., 2002. 383 с.

7.Joseph A. Schumpeter Business cycles. A Theoretical, Historical and Statistical Analysis of the Capitalist Process. New York - Toronto - London: McGraw-Hill Book Company, 1939, 461 pp. URL: https://discoversocialsciences.com/wpcontent/uploads/2018/03/schumpeter_businesscycles_fels.pdf (дата звернення 02.07.2020р.).

8.Шумпетер Й.А. Теория экономического развития. Капитализм, социализм и демократия [предисловие В.С. Автономова; пер. с нем. В.С. Автономова, М.С. Аюбского, А.Ю. Чепуренко; пер. с англ. В.С. Автономова и др.]. М.: Эксмо, 2007. 864 с.

9.Кейнс Дж. М. Общая теория занятости, процента и денег. Избранное. М.: Эксмо, 2007. 960 с. 
10. Алсуф'єва О. О. На шляху до регулювання життєрадісною інтуїцією (Рецепти ДЖ. М. Кейнса). Проблеми економіки та політичної економії. № 2. 2016. URL: http://politeco.nmetau.edu.ua/journals/2/4_a_ua.6.pdf(дата звернення 13.07.2020 p.).

11. Блауг М. 100 великих экономистов после Кейнса. СПб.: Экономикус, 2009. 384 с.

12. Solou R. The Economic of Resources and the Resources of Economics, 1974. 321 p.

13. Сиротинська Н. М. Зародження та розвиток теоретичних основ інновацій. Вісник Національного університету «Львівська політехніка». 2011. № 714: Менеджмент та підприємництво в Україні: етапи становлення і проблеми розвитку. С. 399-405.

14. Еверетт М. Роджерс Дифузія інновацій /Переклад В. Старко. К: Києво-Могилянська академія, 2009. 592с.

15. Твисс Б. Управление научно-техническими нововведениями. М.: Экономика. 1989. 271 с.

16. Mansfield E. Industrial Research and Technological Innovation: An Econometric Analysis. Norton, New York, 1968. 240p.

17. Kuznets S. Modern Economic Growth: Findings and Reflections. Nobel Memorial Lecture, December 1971. In: Les Prix Nobel en 1971. Stockholm, 1972 (reprinted in: American Economic Review, 1973, v.63, p. 247-258).

18. Mensh G. Stalemate Technology: Innovation Overcome the Depression. Cambridge, Masp., 1979. 279 p.

19. Poznanski K. Innowacje w gospodarce kapitalistycznej. Warszawa: PWN, 1979. 32 s.

20. Барютин Л.С. Управление техническими нововведениями в промышленности. Л., 1986. 171 с.

21. Санто Б. Инновации как средство экономического развития. М. : Прогресс, 1990. 296 с.

22. Хучек М. Инновации на предприятиях и их внедрение. М.: Луч, 1992. 162 с.

23. Ілляшенко С. М., Прокопенко О. В. Формування ринку економічних інновацій: економічні основи управління: моногр. Суми: ВТД «Університетська книга», 2002. 278 с.

24. Антонюк Л.Л., Поручник А.М., Савчук В.С. Інновації: теорія, механізм розробки та комерціалізації: моногр. К.: KHEУ, 2003. 394 c.

25. Заблоцький Б. Ф. Економіка й організація інноваційної діяльності : навч. посібник. Львів: Новий Світ - 2000 , 2007. $456 \mathrm{c}$.

26. Сиротинська Н. М. Зародження та розвиток теоретичних основ інновацій. Вісник Національного університету «Львівська політехніка». 2011. № 714: Менеджмент та підприємництво в Україні: етапи становлення і проблеми розвитку. С. 399-405.

27. Пересунько 3. М. Теоретичні аспекти розвитку інноваційної теорії. Ефективна економіка. № 7. 2013. (дата звернення 06.07.2020 p.). URL: http://www.economy.nayka.com.ua/?op=1\&z=2192 (дата звернення 12.07.2020 p.).

28. Закон України «Про інноваційну діяльність» від 04.07.2002 p. № 40-IV. ВВРУ. 2002. № 36. C. 266. URL: https://zakon.rada.gov.ua/laws/show/40-15\#Tехt (дата звернення: 26.07.2020).

29. Скворцов Д.І. Інновація, інноваційність та інноваційний розвиток 3 позицій економічної теорії. URL: http://ena.lp.edu.ua/bitstream/ntb/24636/1/46-309-314.pdf (дата звернення: 30.07.2020p.).

30. Proposed Standard Practice for Surveys of Research and Experimental Development - the Frascati Manual. OECD, 2002. $193 \mathrm{c}$.

31. Руководство Осло. Рекомендации по сбору и анализу данных по инновациям. 3 -е изд., совместная публикация ОЭСР и Евростата / пер. на рус. яз. М.: ГУ «Центр исследований и статистики науки», 2010. 107 с.

32. Manual on the measurement of human resources devoted to S\&T «Canberra manual». 1995. URL: Режим доступу: http://www.oecd.org/dataoecd/34/0/2096025.pdf (дата звернення: 30.07.2020p.).

33. National Innovation Systems. OECD, 1997. 49 p.

34. The Knowledge-based Economy. OECD, 1996. 46 p.

35. TBP Manual. OECD, 1990. 82 p.

\section{References}

1. Cherep A. V., Markova S. V. Otsinka efektyvnosti innovatsiino-investytsiinoi diialnosti pidpryiemstv likero-horilchanoi promyslovosti: monohrafiia. Derzh. vyshch. navch. zakl. "Zaporiz. nats. universytet Ministerstva osvity i nauky, molodi ta sportu Ukrainy”. Zaporizhzhia: Zaporiz. nats. un-t., 2012. 283 p. [in Ukrainian].

2. Smyt A. Yssledovanye o pryrode y prychynakh bohatstva narodov/ vstup. stat. y komment. V.S. Afanaseva. M.: Sotsehyz, 1962. 684 p. [In Russsian].

3. Kondorse J. Eskiz istoricheskoy kartinyi progressa chelovecheskogo razuma; [per. s fr.]. M.: YUtiekny dom "LIBROKOM", 2011. 280 p. [In Russsian].

4. Ricardo D. On The Principles of Political Economy and Taxation. John Murray, 1817.

5. Tugan-Baranovskiy M.I. Promyishlennyie krizisyi. Ocherk iz sotsialnoy istorii Anglii. K.: Naukova dumka, 2004. 368 p. [In Russsian].

6. Kondratev H.D. Bolshie tsiklyi konyyunkturyi i teoriya predvideniya. M., 2002. 383 p. [In Russsian].

7. Joseph A. Schumpeter Business cycles. A Theoretical, Historical and Statistical Analysis of the Capitalist Process. New York, Toronto, London: McGraw-Hill Book Company, 1939, 461 p. Available at: https://discoversocialsciences.com/wpcontent/uploads/2018/03/schumpeter_businesscycles_fels.pdf (accessed 02.07.2020).

8. Shumpeter Y.A. Teoriya ekonomicheskogo razvitiya. Kapitalizm, sotsializm i demokratiya [predislovie V.S. Avtonomova; per. s nem. V.S. Avtonomova, M.S. Lyubskogo, A.Yu. CHepurenko; per. s angl. V.S. Avtonomova i dr.]. M.: Eksmo, 2007. 864 p. [In Russsian].

9. Keyns Dj. M. Obschaya teoriya zanyatosti, protsenta i deneg. Izbrannoe. M.: Eksmo, 2007. 960 p. [In Russsian].

10. Alsufieva O. O. Na shliakhu do rehuliuvannia zhyttieradisnoiu intuitsiieiu (Retsepty DZh. M. Keinsa). Problemy ekonomiky ta politychnoi ekonomii. 2016, No. 2. Available at: http://politeco.nmetau.edu.ua/journals/2/4_a_ua.6.pdf (accessed 13.07.2020) [in Ukrainian].

11. Blaug M. 100 velikih ekonomistov posle Keynsa. SPb.: Ekonomikus, 2009. 384 p. [In Russsian].

12. Solou R. The Economic of Resources and the Resources of Economics, 1974. 321 p. 
13. Syrotynska N. M. Zarodzhennia ta rozvytok teoretychnykh osnov innovatsii. Visnyk Natsionalnoho universytetu "Lvivska politekhnika". 2011, No. 714: Menedzhment ta pidpryiemnytstvo v Ukraini: etapy stanovlennia i problemy rozvytku. pp. 399405. [in Ukrainian].

14. Everett M. Rodzhers Dyfuziia innovatsii /Pereklad V. Starko. K: Kyievo-Mohylianska akademiia, 2009. 592p. [in Ukrainian].

15. Tviss B. Upravlenie nauchno-tehnicheskimi novovvedeniyami. M.: Ekonomika. 1989. 271 p. [In Russsian].

16. Mansfield E. Industrial Research and Technological Innovation: An Econometric Analysis. Norton, New York, 1968. 240 p.

17. Kuznets S. Modern Economic Growth: Findings and Reflections. Nobel Memorial Lecture, December 1971. In: Les Prix Nobel en 1971. Stockholm, 1972 (reprinted in: American Economic Review, 1973, vol. 63, pp. 247-258).

18. Mensh G. Stalemate Technology: Innovation Overcome the Depression. Cambridge, Masp., 1979. 279 p.

19. Poznanski K. Innowacje w gospodarce kapitalistycznej. Warszawa: PWN, 1979. 32 p. [In Polish].

20. Baryutin L.S. Upravlenie tehnicheskimi novovvedeniyami v promyishlennosti. L., 1986. 171 p. [In Russsian].

21. Santo B. Innovatsii kak sredstvo ekonomicheskogo razvitiya. M.: Progress, 1990. 296 p. [In Russsian].

22. Huchek M. Innovatsii na predpriyatiyah i ih vnedrenie. M.: Luch, 1992. 162 p. [In Russsian].

23. Illiashenko S. M., Prokopenko O. V. Formuvannia rynku ekonomichnykh innovatsii: ekonomichni osnovy upravlinnia: monohr. Sumy: VTD "Universytetska knyha", 2002. 278 p. [in Ukrainian].

24. Antoniuk L.L., Poruchnyk A.M., Savchuk V.S. Innovatsii: teoriia, mekhanizm rozrobky ta komertsializatsii: monohr. K.: KNEU, 2003. 394 p. [in Ukrainian].

25. Zablotskyi B. F. Ekonomika y orhanizatsiia innovatsiinoi diialnosti : navch. posibnyk. Lviv: Novyi Svit — 2000, 2007. 456 p. [in Ukrainian].

26. Syrotynska N. M. Zarodzhennia ta rozvytok teoretychnykh osnov innovatsii. Visnyk Natsionalnoho universytetu "Lvivska politekhnika”. 2011, No. 714: Menedzhment ta pidpryiemnytstvo v Ukraini: etapy stanovlennia i problemy rozvytku. pp. 399405. [in Ukrainian].

27. Peresunko Z. M. Teoretychni aspekty rozvytku innovatsiinoi teorii. Efektyvna ekonomika. 2013, No. 7. Available at: http://www.economy.nayka.com.ua/?op=1\&z=2192 (accessed 12.07.2020) [in Ukrainian].

28. Zakon Ukrainy "Pro innovatsiinu diialnist" vid 04.07.2002. No. 40-IV. VVRU. 2002. No. 36. P. 266. [in Ukrainian].

29. Skvortsov D.I. Innovatsiia, innovatsiinist ta innovatsiinyi rozvytok z pozytsii ekonomichnoi teorii. Available at: http://ena.lp.edu.ua/bitstream/ntb/24636/1/46-309-314.pdf (accessed 30.07.2020p.) [in Ukrainian].

30. Proposed Standard Practice for Surveys of Research and Experimental Development - the Frascati Manual. OECD, 2002. $193 \mathrm{p}$.

31. Rukovodstvo Oslo. Rekomendatsii po sboru i analizu dannyih po innovatsiyam. 3-e izd., sovmestnaya publikatsiya OESR i Evrostata / per. na rus. yaz. M.: GU "TSentr issledovaniy i statistiki nauki”, 2010. 107 p. [In Russsian].

32. Manual on the measurement of human resources devoted to S\&T "Canberra manual". 1995. Available at: http://www.oecd.org/dataoecd/34/0/2096025.pdf (accessed 30.07.2020).

33. National Innovation Systems. OECD, 1997. 49 p.

34. The Knowledge-based Economy. OECD, 1996. 46 p.

35. TBP Manual. OECD, 1990. 82 p.

Дата подання публікації 12.08.2020 p. 